\title{
POIPOIA TE KĀKANO, KIA PUĀWAI: NURTURING THE SEED OF COMMUNITY-BASED MĀORI HOUSING RESEARCH
}

\author{
Fiona Cram, Tepora Emery,Violet Aydon-Pou, \\ Zack Makoare, Kathleen Morrison, Morehu Munro, \\ Lisa Pohatu, Nihera Pohatu, Tk Pohatu, Beverly Te Huia
}

\section{INTRODUCTION}

At times, the housing crisis impacting Māori seems overwhelming. Māori home ownership has been plummeting as house prices have been rising, leaving whānau to scramble for accommodation in an increasingly expensive private rental market where paying a high rent is no guarantee of quality housing or tenure security. One outcome is the growing number of whānau housed in emergency or transitional housing for extended periods of time where even though they may not be counted among those who are homeless, they are effectively without a place to call a home.' It is within this context that Māori housing researchers are compelled to document whānau realities, interrogate barriers to whānau securing a home, and highlight what works alongside ideas for innovative housing solutions for Māori.

Over the past 30 years, Kaupapa Māori (by, with, and for Māori) research (KMR) has secured a place in Aotearoa New Zealand, with those undertaking KMR often connected by whakapapa to the places and the people they are working with. ${ }^{2}$ In addition, Kaupapa Māori researchers are committed to building the research capacity of those they collaborate with, so that Māori communities are becoming progressively more active in research and able to centre their research inquires within their own epistemologies (ways of knowing). ${ }^{3}$ Poipoia te kākano, kia puāwai is a programme of housing research that funds four such research inquiries that are by, with, and for local Māori. This paper documents the collaborative journey undertaken to entice community people to be researchers, to tell their own stories about their home place. The result is a portfolio of research that examines people's return to their whenua, where housing is just one part of being 'at home' and ensuring vital and sustainable kāinga tahi. We begin with a brief scene setting out the funding context for this research, followed by a description of the collaborative research development phase, and ending an overview of the projects that emerged and received funding.

\section{KĀINGA TAHI, KĀINGA RUA}

Poipoia te kākano, kia puāwai - Nurture the seed and it will blossom, is funded within the Kāinga Tahi, Kāinga Rua funding stream of the second tranche of the Building Better Homes, Towns and Cities: Ko Ngā Wā Kāinga Hei Papakāinga National Science Challenge (BBHTC). ${ }^{4}$ The vision of the BBHTC challenge encompasses the built environment and the role this environment has in building communities; that is, ka ora kāinga rua. The BBHTC mission is "Manaaki Tangata: Co-created, innovative research that has the potential to transform systems so that people's built environments and communities are hospitable, productive and protective." In 20 I9, BBHTC received 
its second tranche of research funding, with a focus on homes and spaces for generations and thriving communities to "improve the quality and supply of housing and create smart and attractive urban environments." the continuation of the BBHTC's commitment to Kaupapa Māori (by, with, and for Māori) research in its kāinga Tahi, Käinga Rua funding stream, as well as throughout the challenge. This was guided by the aim ofVision Mātauranga "to unlock the science innovation potential of Māori knowledge, resources and people."'

Linda Smith ${ }^{7}$ describes the importance of Kaupapa Māori research privileging Māori knowledge and ways of being and making a positive difference for Māori; that research should be about social change and transformation, alongside community aspirations, development and sovereignty. As Kwesi Prah ${ }^{8}$ has written, "We cannot in all seriousness study ourselves through the eyes of other people's assumptions." Thus, the authentic representation of Indigenous peoples within research is about being true to "the reality of the lived indigenous experience."' Such research needs to speak to the strengths and aspirations of the people as much as it does about the structural barriers to them reaching their full potential and realising their dreams. ${ }^{10}$ In this way, Indigenous people's participation in research will contribute to informing and achieving their goals and aspirations.

Alongside Māori rights to knowledge production embodied in the I840 Treaty of Waitangi," the Declaration on the Rights of Indigenous Peoples (UNDRIP) was adopted by the General Assembly of the United Nations at its 107th plenary meeting, on 13 September 2007. ${ }^{2}$ The UNDRIP affirmed, among many collective rights, our right to name ourselves and our right to our identity. Indigenous peoples throughout the world have the right to protect, develop and innovate our own research. Part I of Article 3I of UNDRIP states:

Indigenous peoples have the right to maintain, control, protect and develop their cultural heritage, traditional knowledge and traditional cultural expressions, as well as the manifestations of their sciences, technologies and cultures, including human and genetic resources, seeds, medicines, knowledge of the properties of fauna and ora, oral traditions, literatures, designs, sports and traditional games and visual and performing arts. They also have the right to maintain, control, protect and develop their intellectual property over such cultural heritage, traditional knowledge, and traditional cultural expressions.

Research methods might involve "sharing food, exchanging gifts, and communicating with the non-living in prayer, in song, in dance or in speech."'13 Swadener and Mutual ${ }^{14}$ set the tone for 'performative' research approaches: the visual and plastic arts, song, oral storytelling, dance, poetry, rituals, 'zines', popular media, and the internet. Therefore, by way of these doctrines and performative research approaches, the scene was set for inviting Māori community researchers, and those aspiring to document the mātauranga of their community, to conceptualise, plan for, undertake and live research as part of their everyday being and doing.

\section{'POIPOIA TE KĀKANO, KIA PUĀWAl'}

The second tranche of the käinga Tahi, Käinga Rua research began in the second half of 2019 with a co-creation phase. This provided us with an opportunity to go into communities and talk with people about their interest in doing research to support their own housing agendas. Aligned with the BBHTC mission, we wanted to facilitate local research that would support local Māori aspirations for hospitable, productive and protective homes and communities. The vision mātauranga (VM) responsiveness of this Poipoia te kākano, kia puāwai research programme is a Kaupapa Māori response, whereby Māori researchers undertake 'local' community-up research with and for Māori. The goal of using Kāinga Tahi, Kāinga Rua funding for rōpū Māori-designed and controlled projects was to enable rōpū to fill gaps they identify in current housing research and knowledge. The objective of Poipoia te kākano, kia puāwai is, therefore, to enable mātauranga Māori about housing solutions that work for Māori to blossom by nurturing research that is by, with, and for whānau, hapū, iwi and Māori communities. 


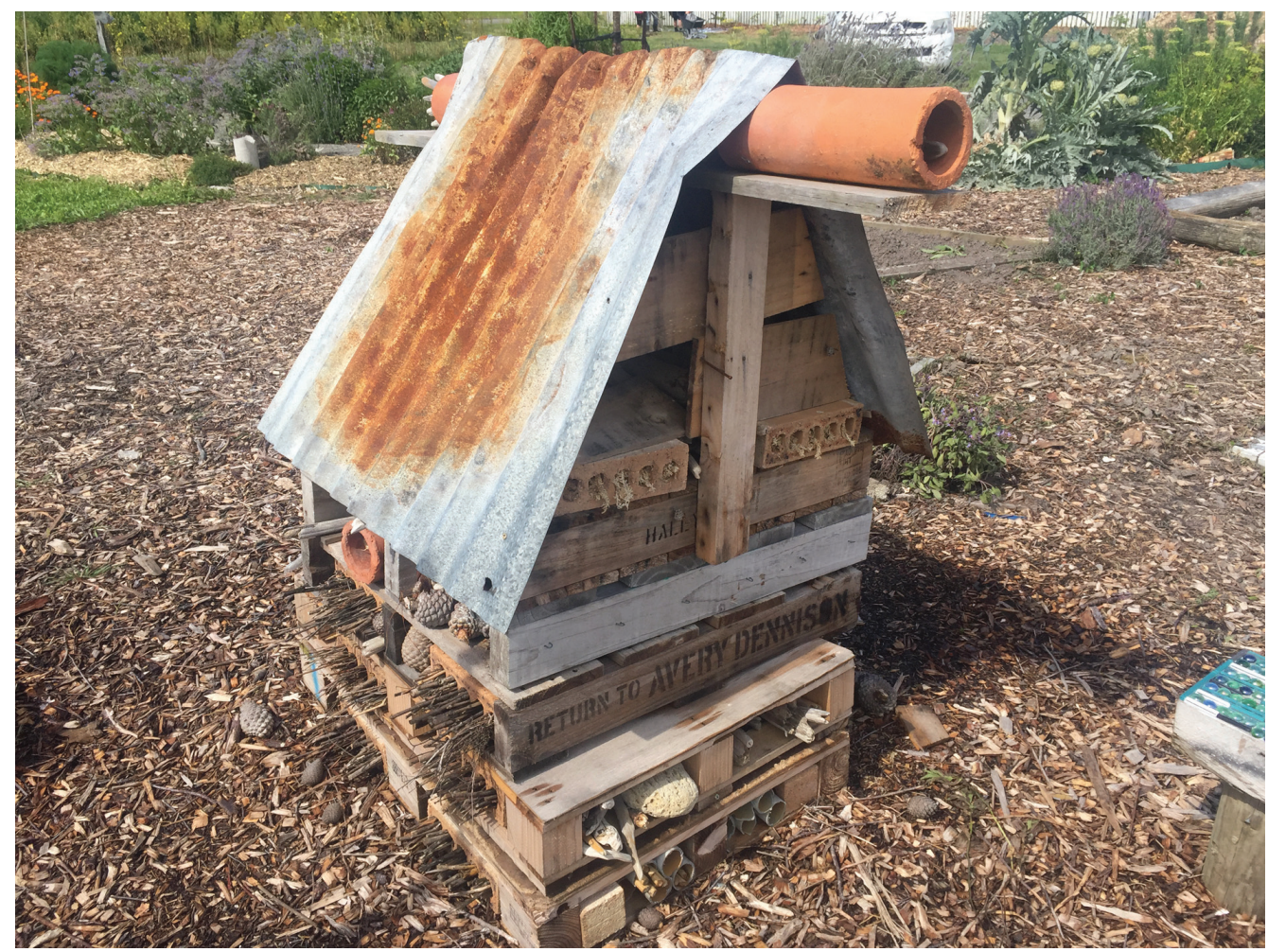

Figure I. Photograph of a bug motel at a Ngāti Porou maara kai.

Our starting point was recruiting local research co-ordinators who could identify and connect with those who they needed to talk to in order to gain input into the creation and design of a local housing research project. These coordinators then had kanohi ki te kanohi (face-to-face) visits with key individuals and whānau to talk about research possibilities, including in at least two locations the co-creation of a research agenda with rangatahi. The result was whānau and hapū led research proposals. The story-telling methodologies were largely qualitative. Researchers would interview, photograph, video record, and keep field notes about housing journeys, reporting back regularly to their respective communities about their findings and documenting what worked as well as any barriers to the fulfilment of housing aspirations.

Figure I is of a bug motel at a Ngāti Porou maara kai. It was constructed to encourage bugs and bees to inhabit the maara. We are trying to construct a metaphorical researcher motel to pōhiri or invite community researchers to know that the maara mātauranga me te maara rangahau - the garden of research and knowledge - is a place they can inhabit and explore and ground themselves with ease and confidence to grow as researchers. Research funds were secured so that these whānau could do their proposed research, with Fiona,Tepora and Lisa as mentors. Maraea Pipi-Takoko is also on board to support rōpū to get the best use out of social media and information technologies when undertaking their research and disseminating their findings. 
The following sections provide an overview of the four research projects.

\section{Papa Kāinga - Ko au ki te whenua, ki te whenua ko au}

Kairangahau: Beverly Te Huia, with rangatahi from Ngāti Mihiroa.

Whāinga paetae: To involve rangatahi as co-researchers in the development of an aspirational plan for living on the whenua.

Waipuka is the name of the lands that stretch south from Ocean Beach, along the east coast of Hawkes Bay to the Waingongoro stream in Waimarama, five kilometres inland, and north to Cape Kidnappers. In the 1950s, the Mãori land, known as Waipuka 3B ICl, was leased under unknown terms for the next 50 years to Pākehā. This resulted in a generation of disconnect from these lands. Twenty years on, whānau and hapū are returning, reconnecting and reclaiming their lands once again. Waipuka is abundant with fresh water, kai moana, and teeming with life, so it is no surprise that Maori occupied this land for centuries. There remain old pa sites, middens, pits, terraces, and artefacts amongst the sand dunes and hills of Waipuka.

With the introduction of the papakāinga legislation, the opportunity for whānau/hapū to live, once again on Māori land has been a welcome solution for many Māori unable to afford the exorbitant cost associated with building infrastructure. This is true for Ngāti Mihiroa who at the start of discussions about Poipoia te käkano, kia puāwai were one year into their papakāinga project, with 12 new whānau homes planned among the existing 32 baches. The hapū have discussed the possibility of creating new kawa, tikanga, wāhi tapu, kāinga noho to meet the needs of the lands and moana in this new environment. The question of what we will bring and what we will leave behind has also been asked; for example, what will happen to our marae in Paki Paki? Will we have a new urupa?

Ngāti Mihiroa rangatahi were invited to lead out on the design of a small, collaborative research project to demonstrate the value (or not) of the hapu telling their stories. In the week of the 2019 Waipuka annual general meeting (AGM), rangatahi met to discuss the papakainga development and what they were interested in investigating. The presence of the rangatahi at the AGM also added another, more conscious level to the meeting, steering the theme to a more future-focused agenda. They came up with five questions and gained permission at the AGM to interview attendees about:

I. What is good about papakāinga?

2. Will the homes on the papakāinga be healthy for the whānau?

3. How do we keep the beach clean?

4. Will we have a sports club?

5. Who are our Kaitiaki?

Overall, rangatahi involvement in research within a papakāinga development project was seen as beneficial. The research itself is founded upon the hypothesis that positive community connectedness is associated with positive individual and social outcomes, and is central to collective identity and, therefore, contributes to wellness. So, it is a little bit about housing and a lot about whenua, guardianship, kawa, tikanga, and whanaungatanga. The proposal gained support from the hapū. 


\section{Te Kinakina Wetlands Project}

Kairangahau: Kathleen Morrison \& Violet Aydon-Pou.

Whāinga paetae: To document the return of the life of the valley that ignites the memories, flavours, sounds, and sights that connect me/us to whenua Māori-to home.

Snake Gully or Te Kinakina encompasses a small valley bordered on one side by a 50 -metre bank covered in native bush which includes 200-300-year-old pōhutukawa and puriri. At the base of this bank runs Pukuranui Stream that has a stony and sandy bottom, meandering, or at times, thundering towards the ocean that lies 200 metres from the northern boundary of Te Kaha 2C2. On the western side of the valley, much of the land has been cleared and fenced off, interrupted by a few pockets of native bush. The valley floor has contributories of spring water and other smaller creeks that drain off neighbouring blocks. In general, the land is seepage wetland, with natural ponds appearing or filling when rain is plentiful. Watercress grows in most of the contributing waterways, small tuna also inhabit these areas. Birdlife is present but sparse due to the disruptive activities of horticulture - maize cropping as well as bird scarers on neighbouring kiwifruit blocks. The partitioning of Te Kaha 2C into Te Kaha 2C2 and Te Kaha $2 \mathrm{Cl}$ has provided separate spaces on Te Kina Kina for landowners to have a safe place to stand; and it rekindles a deep sense of identity and interconnectedness associated with this whenua being ancestral land. The partition has provided us a papakāinga, a place to call home, a place to rest, and a place to dream. The dream is to regenerate and ecologically restore the wetland valley. In so doing, papakāinga will extend to accommodate and embrace the 'others', ko ngā tamariki o Tāne Māhuta me ngā tamariki o Tangaroa.

Fiona and Tepora visited with Kathleen and Violet to walk the land and hear the story of their journey back to the whenua and their aspirations for fulfilling their kaitiaki aspirations. The thought of doing 'research' about the next phase of their journey - the restoration of the wetlands - at first seemed overwhelming in amongst their existing workload. The 'solution' was found in Kathleen's expertise (she has a MFA in photography) to document this journey. The research method proposed is first voice pedagogy as narrative. A photographic essay and accompanying narrative will document the stages of wetland developments.

Te Kinakina Wetlands is a story about mana whenua, whakapapa, and a commitment made to reinstating kāinga for our extended whānau, for the non-human descendants of our environmental atua-Tāne Māhuta, Tangaroa, Rongomātāne, and Haumiatiketike..$^{15}$ In the Wetlands restoration process, creating kāinga for extended whānau serves to thicken the threads of connectivity not only to the 'others' but to our shared primal parents Ranginui and Papatūānuku. According to Harmsworth and Awatere, ${ }^{16}$ Maori well-being and the achievement of Māori aspirations are interdependent on ecosystems; they recommend the use of ecosystem approaches to increase Māori "participation and inclusion in decision-making, to achieve multidimensional aspirational goals and desired indigenous outcomes". 17 In other words, in the process of restoring the ecosystems for the 'others' we will also be restored. 


\section{Mahue Pera Ahu Whenua Trust}

Kairangahau: Te Kura and Nihera Pohatu, with the support of Zack Makoare and Lisa Pohatu.

Whāinga paetae: To document an intergenerational story of mātauranga about the whenua, whakapapa and the fulfilment of aspirations for papakāinga and a return to kāinga tahi.

Ko Kahuranaki te maunga

Ko Kahuranaki te marae

Ko Poukawa te waiu

Ko Takitimu te waka

Ko Ngāti Kahungunu te iwi

Ko Ngāi Te Rangi Koianake te hapū

Ko Te Whatuiapiti te rangatira

Ko Te Hāpuku te tangata

\author{
Ngauao $=$ Te Rangikoianake \\ Karahui $=$ Matewai \\ Te Kaapo = Rameka \\ Nikaore te whare pōuri $=$ Pera Wheraro \\ Mereana Mahue $=$ Hinare Pohatu \\ Ka puta ko mātou ngā uri o Mahue pera ahu whenua \\ trust
}

From the inception of Mahue Pera Ahu Whenua Trust in 1997, the aspiration has been the ability to give whānau the opportunity to learn about farm management, pastoral management and to one day take the land back and manage it for the benefit of whānau. Papakāinga is a setting that embodies oranga and a holistic approach to wellbeing. The vision for Ngāi Te Rangi Koianake — to have Papakāinga on their whenua to keep whānau connected —aligns with the whakataukī (saying) "The future will look like what the past once looked like."'The whole whānau will be part of the journey of realising this whakataukī. Each member of the whānau has an active role, from kaumātua to tamariki, and through wānanga, whānau members will be able to identify, learn and support one another with these roles. The Ngāi Te Rangi Koianake whānau will utilise whakapapa, whenua and whānau to share their whānau Papakāinga journey.

Two rangatahi - a young married couple, Te Kura and Nihera Pohatu - have been identified by the whānau to undertake this research. They will track and monitor stories of this Papakäinga journey. Both have whakapapa links to Ngāti Kahungunu, and Te Kura links to Ngāi Te Rangi Koianake. Both have a love for the environment - Te Kura through spending his weekends out at the Papakāinga maintaining the whenua, and Nihera through physical activity, running marathons, climbing maunga and being outdoors. They are supported by Zack Makoare and Lisa Pohatu.

In the proposed research, whānau will take an intergenerational approach to sharing their story. Kaumātua (older generation) will share their story with the lens to share their moemoeā (dream, vision) for their mokopuna (grandchildren) so that their mokopuna grow up in a safe space. Rangatahi will share their story through the lens of a new generation coming through, eventually having a whānau of their own and living on the Papakāinga. Modern technology such as the drone and GoPro will also be used to document our story. Zack will document the history of the whenua, focusing on what it took to bring whānau together to agree to the development of a papakāinga. Outcomes from this research journey will include strengthening rangatahi research capability and archiving mātauranga to strengthen future generations. 


\section{Te Wairoa}

\section{Kairangahau Morehu Munro}

Whāinga paetae Finding mātauranga Māori solutions through research that will assist our community to continue to grow and flourish.

Te Wairoa is a town in the north of the Hawke's Bay region, located at the mouth of the Wairoa River. It is often known for being New Zealand's most Māori town, with over 62 per cent of the population identifying as Māori. Ngāti Kahungunu o Te Wairoa is the recognised iwi for most of the town's population. Other iwi include Rongomaiwahine, Ngāti Rakai-Paaka, Ngāti Pāhauwera and Ruapani. Te Wairoa is also fiercely loyal to its many hapū and marae; 33 marae reside within a $50 \mathrm{~km}$ radius of the Wairoa Township. The council, supported by local Māori entities including Te Ātaarangi, Reo Rua and surrounding Marae, have asked for Te Wairoa to be seriously considered as one of the first bi-lingual towns in Aotearoa.

The question proposed in the development of this research was: what gaps will Iwi and hapū want to be filled by research, focused on illuminating mātauranga Māori, carried out in collaboration with them? Over a four-week period, Morehu spoke to as many people in Te Wairoa as he could, asking them for feedback on the kaupapa matua. He visited marae, talked to families that own homes and families that have returned to their papakāinga. He also talked to whānau that had remained on their papakāinga and in their tipuna homes. Morehu met with kaumātua, some still living on their papakāinga and others that live in rest homes and kaumātua flats. He also had meetings with local government organisations, property managers and health providers. As a whole, those he spoke to acknowledged that whakapapa and papakāinga are important. They accepted that there were varying degrees of knowledge and understanding regarding mātauranga Māori, kawa, kaupapa, tikanga, whanaungatanga, papakāinga, kaitiakitanga, whakapapa and manaakitanga amongst the group; for some it was of no importance, for others it was of the utmost importance. The group also spoke about an underlying current of jealousy, suspicion and mistrust toward each other.

The research proposed was the collection of community narratives and mātauranga about ahi kaa, with the researcher continuing to work closely with those spoken to in this first phase. For the purpose of this project, ahi kaa is defined as:

1. Ahi kaa e morehu ana: remained on the papakāinga, actively supported the marae and hapū, and maintained the homestead for the whānau.

2. Ahi kaa haere atu hoki mai: do not live on the papakāinga but return regularly to support the marae and hapū.

3. Ahi kaa moe mate: live on the papakāinga but do not support marae and hapū.

This whitiwhiti kōrero (talking and listening) project will be invaluable to projects that are currently being initiated and already running in Te Wairoa. We owe it to the future generations of our whakapapa to do the right thing; finding Mātauranga Māori solutions through research will assist our community to continue to grow and flourish. 


\section{DISCUSSION}

Some years ago, Linda Smith asked a group why they thought Māori should be in the academy. Several answers were proffered before she gave us her opinion; namely, that knowledge is built inside the academy, and Māori have a right to contribute to this knowledge. Since that time, Māori research capacity has been built and community interest in research has strengthened as they have been better represented within research findings. The research projects within Poipoia te käkano, kia puāwai are pushing further into the community as a site of knowing that can inform local thinking, actions and aspirations. They are part of building knowledge in the academy where the academy transforms to embrace Māori knowing where Māori live. In this discussion, we explore how the 'success' of this initiative might be measured.

\section{Measuring success}

A definition of success (see Figure 2) for Poipoia te käkano, kia puāwai is that stories are told by, with, and for the rōpū involved. This telling of their own stories is about mana motuhake, or Māori self-determination over housing research priorities, methodologies, and the utilisation of research findings. In this way the science and mātauranga of Māori housing, homes, places and people can be built and strengthened for Māori vitality and sustainability.

\begin{tabular}{|r|l|}
\hline \multicolumn{2}{|c|}{ KAUPAPA MĀORI RESEARCH } \\
\hline Mana Motuhake & $\begin{array}{l}\text { Sharing Knowledge and Expertise - } \\
\text { Strengthening Research Capability }\end{array}$ \\
\hline \multicolumn{2}{|c|}{ TELLING OUR OWN STORIES } \\
\hline Housing Solutions That Work & Sharing lessons and developing tools \\
\hline Bchieving Housing Aspirations & Strategies to overcome obstacles \\
\hline
\end{tabular}

Figure 2 Defining Success

The success of Poipoia te käkano, kia puāwai will also be defined by the frustrations the stories reveal—frustrations with, for example, whānau, councils, policies and legislation. The stories will also pinpoint the things that work to facilitate people's aspirations of providing housing solutions within their communities, often in their own place and on their land, and perhaps most importantly for their people. This is the dual nature of Kaupapa Māori research; namely, that researchers seek out what promotes the vitality and sustainability of Māori (with this often found within mātauranga Māori) whilst also interrogating the structural barriers to the realisation of Māori potential and the achievement of this vitality and sustainability.

Success, as outlined above, will therefore also inform the development of outputs; including (but not limited to):

- a toolkit about achieving affordable housing in the context of the vitality and sustainability of the whenua, papakāinga, marae, and cultural security

- the sharing of strategies that have worked to restore whānau to their whenua (land) and their aha kaa responsibilities

- a guide for how people can enact their roles as kaitiaki (caretakers) of their whenua and how they can manaaki (host) whānau within their home place, especially whānau who may not otherwise have access to the whenua (for example, whānau with disabilities). 
We are all learners, and we are all teachers in this research journey, just as we try to remain agile and responsive to new interests and issues that arise. We are also able to call on other housing research colleagues when needed. By starting collaboratively with communities and remaining flexible and responsive, we are confident that we have a strong foundation for gaining insights into what makes a place a kāinga tahi for Māori.

\section{CONCLUSION}

The common thread connecting the research projects developed during the co-creation phase in Poipoia te käkano, kia puāwai is Käinga Tahi; that is, research about the places people originate from and still call their home. Enabling home people to do this research with and for themselves extends and embeds Kaupapa Māori research back into communities as a source of nourishment for a vital and sustainable Māori future.

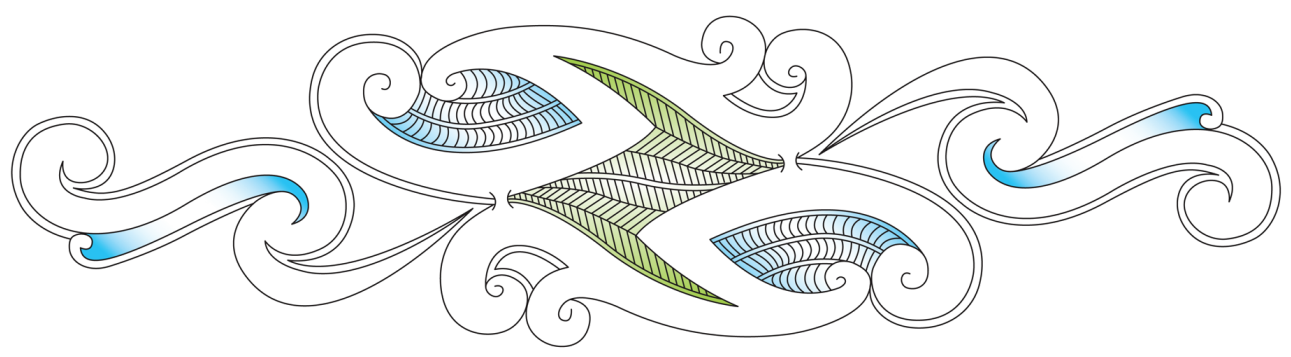

\section{Authors' notes}

The research described in this paper is funded by the Kāinga Tahi, Kāinga Rua funding stream of the Building Better Homes, Towns and Cities National Science Challenge. This paper has been developed from a presentation given at the Kaitiakitaka Māori Research Symposium, Otago Polytechnic, Dunedin, 3 December 2020.

Katoa Ltd. e. fionac@katoa.net.nz Corresponding author.

Kaupapa Māori Research Leader,Toi-Ohomai Institute ofTechnology

Te Kinakina Wetlands

Mahue Pera Ahu Whenua

Te Wairoa

Waipuka Papakāinga 
Violet Aydon-Pou has spent almost 30 years in education, working predominantly at the 'grassroots' level. She has her MA in Social Sciences, been a Fulbright Scholar, and now holds a RTLB (Resource Teacher Learning and Behaviour) position serving schools in the Eastern Bay of Plenty. In her spare time, Violet works with and supports Kathleen to prepare funding applications, Wetland Restoration Progress Reports for whānau as well as funding organisations, and to network with suppliers.

Fiona Cram (Ngāti Pāhauwera, Pākehā) (https://orcid.org/0000-0002-6047-8853) has produced one son, as well as a PhD from the University of Otago (Social and Developmental Psychology). She has over 25 years of Kaupapa Māori (by, with and for Māori) research and evaluation experience with Māori and Iwi organisations and communities, as well as with government agencies, district health boards, and philanthropic organisations. A large portion of this work involves the pursuit of decolonisation, Māori sovereignty, and societal transformation.

Tepora Emery is a kaupapa Māori researcher and evaluator, and a teacher. Belonging to Ngāti Pikiao, Rangiwewehi and Whakaue (Te Arawa waka), and Ngāti Unu, Ngāti Kahu ki Maniapoto (Tainui waka) Tepora has a long record of private and public service, in both lead and supporting roles, across a diverse range of whānau-hapū, iwi, hāpori and Government projects. Tepora is the kaupapa Māori research advisor at Toi Ohomai Institute of Technology and a Principal Lecturer in adult teacher education. The role includes leading and supporting research, evaluation and professional development work both inside the organisation with àkonga, staff and colleagues, and outside of the organisation with whānau, hapū, iwi and community groups.

Zack Makoare has a vision of better housing for his whānau and hapū, living on-site at Puke Aute Te Hauke Heretaunga ki Ngāti Kahungunu Papakāinga whenua. On the personal side, he's 60yrs old, been married 40yrs, and has II mokopuna. He established Te Tai Timu Trust 20 yrs ago, around a kaupapa of wellbeing. The Trust works collaboratively with Mahue-Pera Trust, providing a koha of time and space for Ngā Mokopuna o Ngā Tipuna. He firmly believes that it takes a village to raise a child, and he is committed to the establishment of "Te Pā Oranga', a place of wellness within the Papakäinga.

Kathleen Morrison is a conservationist/Kaitiaki who, alongside of Violet Pou, has designed and planned Te Kinakina Wetlands Restoration Project. She comes from an artistic background with a Master of Fine Arts (MFA) in photography and years of experience as a graphic designer. Having spent the last 10 years living on Te Kinakina, she is now dedicating her time to project manage the wetlands restoration including: the initial design and function of the wetland areas, funding applications, planting schedules, sourcing trees and plants, liaising with community groups, and managing contractors.

Morehu Munro is well-known and connected within the Te Wairoa community, as evidenced by the people he engaged with phase I of this research and the endorsement he received for being the researcher going forward. He is a skilled orator (often being called upon to sit on marae paepae) and gentle spirit, with a good understanding of kawa and tikanga and an inquiring mind.

Lisa Pohatu, of Ngāti Kahungunu ki te Wairoa, ki Heretaunga, Ngāi Tamanuhiri descent, comes to this project as a researcher supporting members of the group. Lisa is motivated and passionate about being able to create opportunities for all Māori to realise their potential. 
Te Kura and Nihera Pohatu were identified by the whānau to undertake this research. They will track and monitor stories of this Papakāinga journey. Both have whakapapa links to Ngāti Kahungunu, and Te Kura links to Ngāi Te Rangi Koianake. When they began the research Te Kura was employed at Manufacturing and Food Producer Company Watties and Nihera was a kaiako at Kohanga Reo. Both have a love for the environment-Te Kura through spending his weekends out at the Papakāinga maintaining the whenua, and Nihera through physical activity, running marathons, climbing maunga and being outdoors.

Beverly Te Huia is a midwife and researcher who is well connected into her hapū of Ngāti Mihiroa. She also lives within the community and interacts regularly with the rangatahi who are aspiring researchers within this project. She is a superb mentor and research coordinator for this project.

I K.Amore, H.Viggers, and P. Howden Chapman, Severe housing deprivation in Aotearoa New Zealand, 20 I 8 (University of Otago, Wellington: He Kāinga Oranga / Housing \& Health Research Programme Department of Public Health, 2020).

2 A. Ormond, F. Cram, and L. Carter, "Researching our relations: Reflections on ethics and marginalisation," Alternative: An international journal of indigenous scholarship, Special supplement (Marginalisation), (2006): I80-198.

3 L.T.Smith, Decolonizing methodologies - Research and Indigenous peoples (2nd edition) (London \& New York: Zed Books, 20 I2).

4 Building Better Homes, Towns and Cities, 2019-2024 Strategy for Phase II. (Wellington: Building Better Homes, Towns and Cities National Science Challenge, 2018).

5 Ministry of Business, Innovation and Emnployment, Building Better Homes, Towns and Cities | Ko ngā wā kāinga hei whakamāhorahora March 5, 20l6, https://www.mbie.govt.nz/science-and-technology/science-and-innovation/fundinginformation-and-opportunities/investment-funds/national-science-challenges/the- I I -challenges/building-better-homestowns-and-cities/.

6 MORST, Vision Mātauranga (Wellington: Ministry of Research Science and Technology, 2007).

7 L.T. Smith, "Fourteen lessons of resistance to exclusion: Learning from the Maori experiences in New Zealand over the last two decades of neo-liberal reform," in State of the Māori nation. Twenty-first-century issues in Aotearoa, ed. M. Mulholland, and contributors (Auckland: Reed Publishing, 2006), 247-260.

8 B. Chilisa, Indigenous research methodologies (2nd ed.) (Thousand Oaks, CA: Sage,2020), 415.

9 C. Weber-Pillwax, "Indigenous research methodology: Exploratory discussion of an elusive subject," Journal of Educational Thought 33, no. I, (1999): $31-46$.

10 L. Malezer, "Challenges in evaluating Indigenous policy," in Better Indigenous policies: The role of evaluation (Roundtable Proceedings ed. Productivity Commission) (Canberra: Productivity Commission, 20 I 3), 69-80.

I I M. Jackson, "Māori health research andTeTiriti o Waitangi," Hui Whakapiripiri:A hui to discuss strategic directions for Māori health research (Wellington:Te Rōpū Rangahau Hauora a Eru Pomare, 1996).

12 United Nations, United Nations Declaration on the Rights of Indigenous Peoples (Geneva: United Nations, 2007).

13 B. Chilisa and G. N. Tsheko, "Mixed methods in Indigenous research: Building relationships for sustainable intervention outcomes," Journal of Mixed Methods Research 8, no. 3 (20 I 4): 222-233, doi: 10.1 I77//15586898I 4527878.

I4 B. B. Swadener and K. Mutua, "Decolonizing performances: Deconstructing the Global Postcolonial," in Handbook of Critical and Indigenous Methodologies, eds N. K. Denzin, Y. S. Lincoln and L. T. Smith, (Los Angelos, London: Sage, 2008), [pp. 31-44]. [please check this reference - I have filled in some missing info but not sure about other parts]

I5 M. Roberts, "Ways of seeing: Whakapapa," Sites: New Series 10 no. I (2013): 93-I20, http://dx.doi.org/I0.III I57/sitesvoll Oiss lid236.

I6 G. R. Harmsworth and S. Awatere, "Indigenous Māori knowledge and perspectives of ecosystems," in Ecosystem services in New Zealand - conditions and trends, ed. J. R. Dymond, (Lincoln: Manaaki Whenua Press, 20I 3), 274-286.

17 Ibid p.274 